\title{
Influences of the Global Deterioration Scale according to Routine Blood Chemistry Results
}

\author{
Sun-Gyu Kim ${ }^{1}$, Chang-Eun Park ${ }^{2}$ \\ ${ }^{1}$ Department of Laboratory Medicine, Gyeonggi Province Medical Center Ansung Hospital, Ansung, Korea \\ ${ }^{2}$ Department of Biomedical Laboratory Science, Molecular Diagnostics Research Institute, Namseoul University, Cheonan, Korea
}

\section{통상적 혈액화학 결과에서 전반적 퇴화 척도의 영향성}

김선규 $^{1}$, 박창은 $^{2}$

${ }^{1}$ 경기도의료원 안성병원 진단검사의학과, ${ }^{2}$ 남서울대학교 임상병리학과·분자진단연구소

\section{ARTICLE INFO}

Received July 19, 2019

Revised $1^{\text {st }}$ July 30, 2019

Revised $2^{\text {nd }}$ August 14, 2019

Accepted August 15, 2019

\section{Key words}

Alanine aminotransferase

Creatinine

Global deterioration scale

Seoul neuropsychological screening

battery-II

Sodium

\begin{abstract}
Neurocognitive testing commonly uses the MMSE (Mini-Mental State Examination) to evaluate the overall cognitive function of patients at outpatient clinics, but the MMSE has recently been extensively used in the SNSB II (Seoul Neuropsychological Screening Battery II) for making diagnoses. We retrospectively investigated the results of routine neurocognitive tests and the results of the blood tests of 120 elderly patients who had been referred to a South Central Medical Center from 2017 to 2018 and who had been examined at a public health center. These subjects' space-time capability was high on the sub-region of the global deterioration scale (GDS). GDS showed a significant increase as the Na decreased on the electrolyte analysis. The subjects' concentration, their language-based orientation for space and time, their memory, and their scores for the frontal lobe function on GDS showed statistically significant reductions $(P<0.001)$ For the normal and abnormal groups according to the ALT and creatinine levels, the frontal/execute function areas showed statistically significant differences $(P<0.001)$ as well as negative correlation between GDS and ALT ( $P<0.01)$. In conclusion, this study provides basic information to develop test items that are important for patient screening and diagnosis, and several routine blood chemistry factors provide basic information for diagnosing and assessing the status and progress of cognitively impaired patients.
\end{abstract}

Copyright $\odot 2019$ The Korean Society for Clinical Laboratory Science. All rights reserved.

\section{INTRODUCTION}

Neuropsychological tests are tests that comprehensively assess the overall cognitive function. Provide the necessary information for early diagnosis and differential diagnosis of cognitive dysfunction, evaluation of disease progression and treatment. It is composed of areas of

\footnotetext{
* Corresponding author: Chang-Eun Park

Department of Biomedical Laboratory Science, Molecular Diagnostics Research Institute, Namseoul University, 91 Daehak-ro, Seonghwan-eup, Seobuk-gu, Cheonan 31020, Korea

E-mail: eun2777@hanmail.net

* ORCID: https://orcid.org/0000-0003-4259-7928
}

cognitive function. The area includes five areas: attention ability, language and related functions, time and space functions, memory and frontal management functions. Depending on the purpose of the neuropsychological test, the total cognitive function may be assessed or may include only the area of interest.

And it can be performed in detail and long, and the examination is conducted in a short time. For meaningful clinical interpretation, it is recommended to perform standardized and reliable tests. Since the patient and the examiner are usually examined by answering questions 
and instructions, consideration of the physical and emotional state of the patient is essential for performing and interpreting the neuropsychological test. There are so many neuropsychological tests that can not be counted, but Seoul Neuropsychological Screening Battery (SNSB) is the most commonly used test in Korea.

A comprehensive and in-depth assessment of cognitive function provides useful information on early diagnosis of dementia and causative disease. SNSB was developed for the purpose of assessing the efficacy of therapeutic agents. The test items include five cognitive domain tests, as well as Korean version of Mini-Mental State Examination (K-MMSE), geriatric depression scale [1] and barthel index. K-MMSE reported a satisfactory sensitivity (70.3 82.7\%) and specificity (91.3\%) when applied to a 23-point cut-off point in the validity study of hospital dementia patients [2, 3]. K-MMSE has been mainly used in clinical settings, and is sometimes used as a screening test for the prevalence of dementia led by neurologists.

When compared with comprehensive neuropsychological tests such as the SNSB, data from K-MMSE tests that applied the criteria according to education and age derived false negative rate results over 19.7\% [4]. Several previous studies including the SNSB, identified that the MMSE did not adequately evaluate executive function [5].

Recently, high high-density lipoprotein cholesterol (HDL-C) levels in midlife are inversely associated with both late-life mild cognitive impairment (MCI) and dementia. Midlife HDL-C thus has the potential to be used as a marker of late-life cognitive impairment [6].

Presbycusis is the general term applied to ARHL (age-related hearing loss). The risk factors for presbycusis include noise exposure, smoking, medication, hypertension, family history and other factors [7]. Dementia is a chronic and progressive deterioration disease characterized by cognitive dysfunction and abnormal mental behavior. It has become the greatest global challenge for health and social care in the 21st century [8].

Also, Vitamin B complex acts on the supply and metabolism of energy. Vitamin B12 and B9 (folic acid) are closely related to the onset and prevention of dementia genetic tests show that family dementia tends to be relic and that there are three genes that cause it, but it accounts for $5 \%$ to $10 \%$ of all dementia. If the family history of dementia appears, an assessment of hereditary dementia is needed. Sporadic Alzheimer's disease, which accounts for the rest of the disease, causes dementia by compounding multiple risk perceptions. Among them, having a single Apo protein type 4 genes, a risk factor that causes sporadic Alzheimer's disease, causes $2 \sim 3$ times the risk of dementia than those without genes, having two increases the risk by more than 10 times. It is difficult to diagnose dementia with one Apo protein gene. However, it provides clinical information on the progression of dementia conversion rate or dementia in mild cognitive impairment.

The literature on minerals and cognitive impairment associated with dementia is limited. Previous reported that increased dietary intake of potassium, calcium, and magnesium reduced the risk of all-cause dementia especially vascular dementia. The risk of $\mathrm{AD}$ tended to decrease with higher reported dietary mineral intake, but there was no significant linear progression [9]. The significant interaction between fasting glucose and sex suggested fasting glucose levels were deleterious to short-term verbal memory performance, particularly among men [10].

The few tests that have merit as broader screening tests in asymptomatic patients include serum glucose, blood urea nitrogen (BUN), creatinine, and urinalysis. Patients on psychotropic medications should be monitored for side effects of that particular therapy. Further prospective data are needed to develop cost-efficient, population-specific diagnostic strategies [11, 12].

Recently reported studies have been conducted to estimate the stage of disease by finding biomarkers through blood tests in cognitive dysfunction groups such as dementia and Alzheimer's disease [7-10]. However, blood analysis of biomarkers is rarely performed in patients with cognitive dysfunction. Therefore, we conducted the study from the early 90's [11, 12] to investigate the relationship between routine blood chemistry test and GDS level. Ultimately, routine blood 
chemistry factors provide basic information about the diagnosis and progress of cognitive impairment subjects.

\section{MATERIALS AND METHODS}

\section{Subjects}

The subjects' personal information was not collected and retrospectively investigated through routine blood chemistry results and GDS. In the results (2017 2018 years), Among the 120 patients who first visited the neurologist for cognitive function test and measured the GDS and performed routine blood chemistry tests. This study is a retrospective study. Subjects were the elderly, including the elderly who were referred to the hospital from the public health center to the hospital. This study has been conducted according to the principles expressed in the Declaration of Helsinki (approved and exemption by Institutional Review Board No. 1041479-HR-201805-019 at Namseoul University).

\section{Analysis of routine blood chemistry}

This was a retrospective cohort study conducted on data from the total cholesterol (TC), total bilirubin (TB), uric acid (UA), aspartate aminotransferase (AST), alanine aminotransferase (ALT), blood urea nitrogen (BUN), creatinine $(\mathrm{Cr})$, sodium $(\mathrm{Na})$, potassium $(\mathrm{K})$, chloride $(\mathrm{Cl})$, in Gyeongi province medical center Ansung hospital (2017), which is the most recent data that measured. Laboratory values determined using standard laboratory techniques on a TBA-2000FR (Toshiba LTD., Tokyo, Japan) The data was a randomized survey to conducted by outpatients in Gyeongi province medical center Ansung hospital.

\section{Seoul neuropsychological scanning battery}

The SNSB-II evaluates four cognitive factors such as memory, language skills, space-time functions, and executive function. The evaluation of each cognitive domain conformed to the criteria of SNSB-II. Memory was evaluated by delayed recall using Seoul Verbal Learning Test (SVLT), and the Rey Complex Figure Test (RCFT).
Language skills were assessed by naming Korean-Boston Naming Test (K-BNT), and time and space function was evaluated using the RCFT. Executive function was evaluated using a variety of tests, including the motor control and perseveration test (motor impersistence, contrasting program, go-no-go, fist-edge-palm, alternating hand movement, alternating square and triangle, and Luria loop) the controlled word association test (COWAT) and the stroop color reading forward reaction of Korean-Color Word Stroop Test (KCWST).

The SNSB has been modified and complemented to produce the SNSB-II. The SNSB-II expands the age criteria to 45 years old to 90 years old from its previous range of 55 years to 80 years of age.

For SNSB-II assessment, area-specific disability criteria were defined as follows, in accordance with the standards of cognitive dysfunction defined by SNSB-II.

(1) Memory: at least one is abnormal in A and B. A (Verbal memory): SVLT delayed recall scores are abnormal $(<15 \%)$. B (Visual memory): RCFT delayed recall scores are abnormal $(<15 \%)$.

(2) Language skills: K-BNT (full) is abnormal $(<15 \%)$.

(3) Space-time function: the RCFT copy is abnormal $(<15 \%)$.

(4) Executive dysfunction: two or more are abnormal in $\mathrm{A}, \mathrm{B}$, and $\mathrm{C}$.

A (Motor examination): three kinds or more are abnormal in the following tests: motor impersistence, contrasting program, go-no-go, fist-edge-palm, alternating hand movement, alternating square \& triangle, and Luria loop.

B (COWAT): at least one or more is abnormal in the following three tests: animal, supermarket, and Hangul consonants.

C: Stroop color reading forward reaction is abnormal $(<15 \%)$.

The assessment methods for global deterioration scale (GDS) cognitive impairment include GDS 1 (no cognitive impairment), GDS 2 (very mild cognitive impairment), GDS 3 (minor cognitive impairment), GDS 4 (middle cognitive impairment), GDS 5 (initial cognitive impairment), 
GDS 6 (severe cognitive impairment) and GDS 7 (the last stage severe cognitive impairment)[13]. GDS is accurately reflecting the progression of the disorder of the primary degenerative dementia. Not influenced by educational, cultural, socioeconomic, and other biases.

\section{Statistical analysis}

The level of statistical significance was defined as having a $P$-value of less than 0.05 or 0.01 . Data were analyzed using PAWS version 22.0 (SPSS Inc., Chicago, IL, USA). The results of score and each blood chemistry analysis value by region of neurocognitive test were calculated by average and standard deviation. The analysis was conducted by $t$-test and ANOVA (Scheffe Post Hoc test) according to the distribution of neurocognitive test, seasonality, and blood chemistry test factors (including electrolytes). The correlation between blood chemical factors, seasonality, and blood chemistry test factors was analyzed as Pearson Correlation Coefficient. We used the parametric method to identify correlations between the indicators.

\section{RESULTS}

\section{Distribution of characteristics parameters in clinical} patients

The frequency of characteristics parameters of the participants are shown in Table 1. The distribution of total cholesterol was 28 (23.3\%) out of reference, and 46 (38.3\%) was also distributed. Most of the remaining items were less than $10 \%$. GDS ratings were the highest at 3.0 with $45(37.5 \%)$ and 5.0, 4.0, 2.0 and 6.0.

\section{Correlation between blood test factors and GDS grade}

The changes in blood test factors according to the GDS grade showed that the GDS showed a significant decline in GDS as the GDS increased $(P<0.05)$, and AST and ALT

Table 1. Distribution and frequency of analysis factors in the study participants $(N=120)$

\begin{tabular}{|c|c|c|c|c|c|}
\hline Characteristic & Variables & $N$ & $\%$ & Reference value & Mean \pm SD \\
\hline \multirow[t]{2}{*}{$\mathrm{TC}(\mathrm{mg} / \mathrm{dL})$} & Abnoramal & 28 & 23.3 & $<200$ & $190.0 \pm 38.6$ \\
\hline & Normal & 92 & 76.7 & & \\
\hline \multirow[t]{2}{*}{ TB (mg/dL) } & Abnoramal & 2 & 1.7 & $<1.3$ & $0.6 \pm 0.2$ \\
\hline & Normal & 118 & 98.3 & & \\
\hline \multirow[t]{2}{*}{ UA (mg/dL) } & Abnoramal & 14 & 11.7 & $2.4 \sim 7.0$ & $4.8 \pm 1.5$ \\
\hline & Normal & 106 & 88.3 & & \\
\hline \multirow[t]{2}{*}{ AST (U/L) } & Abnoramal & 8 & 6.7 & $<40$ & $24.9 \pm 8.8$ \\
\hline & Normal & 112 & 93.3 & & \\
\hline \multirow[t]{2}{*}{ ALT (U/L) } & Abnoramal & 6 & 5.0 & $<40$ & $18.9 \pm 10.9$ \\
\hline & Normal & 114 & 95.0 & & \\
\hline \multirow[t]{2}{*}{ BUN (mg/dL) } & Abnoramal & 10 & 8.3 & $6.0 \sim 20.0$ & $15.9 \pm 5.6$ \\
\hline & Normal & 110 & 91.7 & & \\
\hline \multirow[t]{2}{*}{$\mathrm{Cr}(\mathrm{mg} / \mathrm{dL})$} & Abnoramal & 46 & 38.3 & $0.50 \sim 1.30$ & $0.9 \pm 0.4$ \\
\hline & Normal & 74 & 61.7 & & \\
\hline \multirow[t]{2}{*}{$\mathrm{Na}(\mathrm{mmol} / \mathrm{L})$} & Abnoramal & 2 & 1.7 & $136 \sim 145$ & $138.9 \pm 2.7$ \\
\hline & Normal & 118 & 98.3 & & \\
\hline \multirow[t]{2}{*}{$\mathrm{K}(\mathrm{mmol} / \mathrm{L})$} & Abnoramal & 3 & 2.5 & $3.5 \sim 5.5$ & $4.2 \pm 0.4$ \\
\hline & Normal & 117 & 97.5 & & \\
\hline \multirow[t]{2}{*}{$\mathrm{Cl}(\mathrm{mmol} / \mathrm{L})$} & Abnoramal & 4 & 3.3 & $98 \sim 107$ & $103.2 \pm 3.1$ \\
\hline & Normal & 116 & 96.7 & & \\
\hline \multirow[t]{5}{*}{ GDS (grade) } & 2.0 & 8 & 6.7 & & $3.85 \pm 1.0$ \\
\hline & 3.0 & 45 & 37.5 & & \\
\hline & 4.0 & 27 & 22.5 & & \\
\hline & 5.0 & 37 & 30.8 & & \\
\hline & 6.0 & 3 & 2.5 & & \\
\hline
\end{tabular}

Abbreviations: TC, total cholesterol; TB, total bilirubin; UA, uric acid; AST, aspartate aminotransferase; ALT, alanine aminotransferase; BUN, blood urea nitrogen; $\mathrm{Cr}$, creatinine; $\mathrm{Na}$, sodium; K, potassium; $\mathrm{Cl}$, chloride; GDS, global deterioration scale. 
showed a significant decrease in GDS 4.0 group compared to 5.0 group in the total Bilirubin group. Creatinine also significantly decreased levels of GDS 3.0, 4.0, and 5.0 to $6.0(P<0.05)$. In the analysis of electrolytes, the levels of $\mathrm{Na}$ from 2.0 to 5.0 decreased from $6.0(P<0.05)$, and the levels of $\mathrm{K}$ from 2.0 to 5.0 increased from $6.0(P<0.05)$. Overall, the one-way analysis showed statistically significant distribution of the GDS grade $(P<0.05)$ (Table 2$)$.

\section{Correlation of GDS subcategory factors according to GDS grade}

The changes in sub-domains according to the GDS grade showed statistical significance in all sub-domains $(P<0.001)$, significantly lower in concentration at GDS 5.0 and 6.0, and lower in language than GDS 2.0 at 3.0, 4.0 and 5.0. Visuospatial function was significantly lower than GDS 2.0 and 3.0 at 4.0, 5.0, and 6.0, and memory and frontal/executive function decreased as GDS levels increased. They were all statistically significant $(P<0.05)$ (Table 3).

\section{Difference of blood factors according to GDS subcategory}

The association of blood factors with GDS subcategory showed statistical differences in the levels of visual function in the normal and abnormal groups of total cholesterol $(P<0.05)$. In addition, statistical significance was shown in the front/execute function areas in the summit and abnormal groups of ALT and Creatinine $(P<0.001$, $P=0.019$ ). The electrolyte factor has a significantly smaller population of abnormal groups, but it has statistically significance in $\mathrm{Na}, \mathrm{Cl}$, language, visuospatial function, and frontal/executive function $(P<0.05)$ (Table 4).

\section{Correlation of blood factors and GDS}

Table 5 showed the significant correlation between

Table 2. Difference of parameters in according to the level of GDS

\begin{tabular}{|c|c|c|c|c|c|c|c|c|}
\hline \multirow{2}{*}{ Variables } & \multicolumn{5}{|c|}{ GDS grade $(\mathrm{N})$} & \multirow{2}{*}{ Schéffe } & \multirow{2}{*}{$\mathrm{F}$} & \multirow{2}{*}{$P$} \\
\hline & $2.0^{\mathrm{a}}(8)$ & $3.0^{\mathrm{b}}(45)$ & $4.0^{c}(27)$ & $5.0^{d}(37)$ & $6.0^{\mathrm{e}}(3)$ & & & \\
\hline TC & $199.1 \pm 40.0$ & $192.9 \pm 40.9$ & $187.9 \pm 40.2$ & $187.7 \pm 32.3$ & $169.0 \pm 69.3$ & & 0.440 & 0.779 \\
\hline TB & $0.5 \pm 0.1$ & $0.6 \pm 0.2$ & $0.6 \pm 0.2$ & $0.5 \pm 0.2$ & $0.6 \pm 0.1$ & $c>d$ & 1.345 & 0.258 \\
\hline UA & $4.3 \pm 0.5$ & $4.9 \pm 1.5$ & $4.9 \pm 1.7$ & $4.6 \pm 1.5$ & $3.7 \pm 1.3$ & & 0.875 & 0.481 \\
\hline AST & $30.1 \pm 13.7$ & $25.2 \pm 9.7$ & $25.3 \pm 6.1$ & $23.1 \pm 8.0$ & $22.6 \pm 6.1$ & $a>d$ & 1.142 & 0.340 \\
\hline ALT & $27.0 \pm 14.8$ & $20.6 \pm 11.8$ & $18.2 \pm 8.5$ & $16.1 \pm 9.8$ & $13.6 \pm 5.7$ & $a>c>d$ & 2.277 & 0.065 \\
\hline BUN & $15.2 \pm 3.6$ & $15.2 \pm 4.9$ & $16.5 \pm 5.9$ & $16.5 \pm 6.7$ & $12.6 \pm 1.5$ & & 0.617 & 0.651 \\
\hline $\mathrm{Cr}$ & $0.8 \pm 0.1$ & $0.9 \pm 0.2$ & $1.0 \pm 0.5$ & $1.0 \pm 0.4$ & $0.7 \pm 0.0$ & $b>e, c>e, d>e$ & 0.979 & 0.422 \\
\hline $\mathrm{Na}$ & $139.1 \pm 1.9$ & $139.4 \pm 2.0$ & $139.4 \pm 2.8$ & $138.4 \pm 2.4$ & $133.3 \pm 7.3$ & $a>e, b>e, c>e, d>e$ & 4.665 & $0.002^{*}$ \\
\hline K & $4.2 \pm 0.4$ & $4.2 \pm 0.2$ & $4.2 \pm 0.3$ & $4.2 \pm 0.5$ & $4.4 \pm 0.9$ & $\mathrm{a}<\mathrm{e}, \mathrm{b}<\mathrm{e}, \mathrm{c}<\mathrm{e}, \mathrm{d}<\mathrm{e}$ & 0.319 & 0.865 \\
\hline $\mathrm{Cl}$ & $103.5 \pm 1.4$ & $103.4 \pm 2.3$ & $103.1 \pm 3.8$ & $103.4 \pm 3.2$ & $98.3 \pm 7.0$ & & 1.959 & 0.105 \\
\hline
\end{tabular}

Abbreviations: See Table 1.

${ }^{*} p<0.05$.

Table 3. Difference of GDS subcategory in according to the level of GDS

\begin{tabular}{|c|c|c|c|c|c|c|c|c|}
\hline \multirow{2}{*}{ Variables } & \multicolumn{5}{|c|}{ GDS grade $(\mathrm{N})$} & \multirow{2}{*}{ Schéffe } & \multirow{2}{*}{$\mathrm{F}$} & \multirow{2}{*}{$P$} \\
\hline & $2.0^{\mathrm{a}}(8)$ & $3.0^{b}(45)$ & $4.0^{c}(27)$ & $5.0^{\mathrm{d}}(37)$ & $6.0^{\mathrm{e}}(3)$ & & & \\
\hline Attention & $27.9 \pm 28.6$ & $29.4 \pm 22.7$ & $14.9 \pm 18.2$ & $9.8 \pm 11.3$ & $6.5 \pm 11.0$ & $a>d, b>c>d, c>e$ & 6.530 & $0.000^{*}$ \\
\hline Language & $52.2 \pm 27.6$ & $48.2 \pm 23.7$ & $32.2 \pm 28.2$ & $25.2 \pm 30.3$ & $33.1 \pm 46.8$ & $a>d, b>c>d$ & 4.342 & $0.003^{*}$ \\
\hline VF & $46.7 \pm 34.3$ & $34.1 \pm 32.7$ & $9.0 \pm 16.1$ & $6.1 \pm 15.4$ & $0.7 \pm 1.1$ & $a>c, d \quad b>d, e$ & 10.648 & $0.000^{*}$ \\
\hline Memory & $45.9 \pm 17.2$ & $14.2 \pm 19.8$ & $9.3 \pm 9.9$ & $5.4 \pm 7.4$ & $0.3 \pm 0.4$ & $a>b, c, d, e \quad b>d$ & 13.993 & $0.000^{*}$ \\
\hline $\mathrm{FE}$ & $33.0 \pm 27.4$ & $17.3 \pm 21.5$ & $7.3 \pm 19.8$ & $3.6 \pm 9.5$ & $0.03 \pm 0.05$ & $a>b, c, d, e$ & 6.151 & $0.000^{*}$ \\
\hline
\end{tabular}

Abbreviations: VF, Visuospatial function; FE, Frontal/Executive function.

${ }^{*} P<0.05$. 
Table 4. Difference of GDS subcategory in according to the level of parameters (abnormal/normal)

\begin{tabular}{|c|c|c|c|c|c|c|}
\hline \multirow{2}{*}{\multicolumn{2}{|c|}{ Variables }} & \multicolumn{5}{|c|}{ GDS subcategory } \\
\hline & & \multirow{2}{*}{$\begin{array}{c}\text { Attention } \\
25.2 . \pm 23.5\end{array}$} & \multirow{2}{*}{$\begin{array}{l}\text { Language } \\
41.4 \pm 25.6\end{array}$} & \multirow{2}{*}{$\frac{V F}{29.8 \pm 29.7}$} & \multirow{2}{*}{$\frac{\text { Memory }}{13.6 \pm 18.6}$} & \multirow{2}{*}{$\frac{\mathrm{FE}}{11.5 \pm 19.0}$} \\
\hline TC & Abnormal & & & & & \\
\hline & Normal & $17.7 \pm 19.6$ & $36.2 \pm 30.2$ & $16.8 \pm 27.6$ & $11.7 \pm 16.9$ & $11.4 \pm 20.3$ \\
\hline & $\chi^{2}(P)$ & $2.126(0.097)$ & $2.011(0.407)$ & $2.328\left(0.035^{\star}\right)$ & $0.602(0.616)$ & $0.048(0.975)$ \\
\hline \multirow[t]{3}{*}{ TB } & Abnormal & $5.5 \pm 3.6$ & $32.4 \pm 7.6$ & $14.1 \pm 19.9$ & $6.8 \pm 9.0$ & $11.9 \pm 16.9$ \\
\hline & Normal & $19.7 \pm 20.9$ & $37.5 \pm 29.4$ & $20.0 \pm 28.7$ & $12.2 \pm 17.3$ & $11.4 \pm 20.1$ \\
\hline & $\chi^{2}(P)$ & $1.767(0.341)$ & $3.950(0.508)$ & $0.853(0.749)$ & $0.696(0.660)$ & $0.071(0.973)$ \\
\hline \multirow[t]{3}{*}{ UA } & Abnormal & $24.6 \pm 26.9$ & $27.2 \pm 23.8$ & $15.7 \pm 18.5$ & $7.2 \pm 8.7$ & $10.1 \pm 17.4$ \\
\hline & Normal & $18.8 \pm 19.9$ & $38.7 \pm 29.6$ & $20.4 \pm 29.6$ & $12.8 \pm 18.0$ & $11.6 \pm 20.3$ \\
\hline & $\chi^{2}(P)$ & $3.104(0.330)$ & $3.147(0.167)$ & $5.516(0.421)$ & $5.641(0.065)$ & $0.136(0.795)$ \\
\hline \multirow[t]{3}{*}{ AST } & Abnormal & $12.6 \pm 18.3$ & $41.0 \pm 29.2$ & $20.3 \pm 26.1$ & $13.7 \pm 18.9$ & $18.6 \pm 29.9$ \\
\hline & Normal & $19.9 \pm 20.9$ & $37.1 \pm 29.3$ & $19.8 \pm 28.8$ & $12.0 \pm 17.2$ & $10.9 \pm 19.1$ \\
\hline & $\chi^{2}(P)$ & $0.026(0.309)$ & $0.534(0.722)$ & $0.494(0.962)$ & $0.071(0.795)$ & $2.247(0.298)$ \\
\hline \multirow[t]{3}{*}{ ALT } & Abnormal & $17.7 \pm 16.7$ & $32.7 \pm 22.9$ & $21.9 \pm 29.0$ & $9.1 \pm 11.3$ & $1.9 \pm 3.0$ \\
\hline & Normal & $19.5 \pm 21.0$ & $37.6 \pm 29.5$ & $19.8 \pm 28.6$ & $12.3 \pm 17.5$ & $11.9 \pm 20.3$ \\
\hline & $\chi^{2}(P)$ & $0.100(0.831)$ & $1.374(0.688)$ & $0.083(0.860)$ & $0.850(0.662)$ & $4.943\left(0.000^{\star}\right)$ \\
\hline \multirow[t]{3}{*}{ BUN } & Abnormal & $19.6 \pm 22.6$ & $35.6 \pm 29.9$ & $14.0 \pm 22.3$ & $8.5 \pm 11.4$ & $7.3 \pm 17.6$ \\
\hline & Normal & $19.4 \pm 20.7$ & $37.6 \pm 29.2$ & $20.4 \pm 29.0$ & $12.5 \pm 17.7$ & $11.8 \pm 20.2$ \\
\hline & $\chi^{2}(P)$ & $0.025(0.975)$ & $0.445(0.841)$ & $1.749(0.499)$ & $1.553(0.492)$ & $0.791(0.500)$ \\
\hline \multirow[t]{3}{*}{$\mathrm{Cr}$} & Abnormal & $16.3 \pm 18.0$ & $36.9 \pm 27.4$ & $15.9 \pm 23.8$ & $9.1 \pm 14.7$ & $6.6 \pm 13.2$ \\
\hline & Normal & $21.4 \pm 22.2$ & $37.7 \pm 30.4$ & $22.3 \pm 31.0$ & $14.0 \pm 18.5$ & $14.4 \pm 22.8$ \\
\hline & $\chi^{2}(P)$ & $2.094(0.199)$ & $2.666(0.880)$ & $9.420(0.202)$ & $6.146(0.107)$ & $12.134\left(0.019^{\star}\right)$ \\
\hline \multirow[t]{3}{*}{$\mathrm{Na}$} & Abnormal & $11.8 \pm 13.5$ & $0.3 \pm 0.3$ & $0.1 \pm 0.0$ & $3.1 \pm 4.2$ & $0.05 \pm 0.07$ \\
\hline & Normal & $19.6 \pm 20.9$ & $38.0 \pm 29.0$ & $20.2 \pm 28.6$ & $12.3 \pm 17.3$ & $11.6 \pm 20.1$ \\
\hline & $\chi^{2}(P)$ & $0.384(0.604)$ & $5.905\left(0.000^{\star}\right)$ & $4.974\left(0.000^{\star}\right)$ & $1.563(0.456)$ & $2.260(0.417)$ \\
\hline \multirow[t]{3}{*}{ K } & Abnormal & $9.3 \pm 10.9$ & $32.9 \pm 47.0$ & $8.2 \pm 12.4$ & $3.2 \pm 3.0$ & $1.0 \pm 1.8$ \\
\hline & Normal & $19.7 \pm 20.9$ & $37.5 \pm 28.9$ & $20.2 \pm 28.7$ & $12.4 \pm 17.4$ & $11.7 \pm 20.1$ \\
\hline & $\chi^{2}(P)$ & $0.906(0.394)$ & $1.702(0.787)$ & $2.820(0.477)$ & $2.774(0.368)$ & $2.807(0.363)$ \\
\hline \multirow[t]{3}{*}{$\mathrm{Cl}$} & Abnormal & $9.7 \pm 10.7$ & $51.1 \pm 41.5$ & $0.6 \pm 0.9$ & $6.9 \pm 12.7$ & $0.3 \pm 0.4$ \\
\hline & Normal & $19.8 \pm 21.0$ & $36.9 \pm 28.8$ & $20.5 \pm 28.7$ & $12.3 \pm 17.4$ & $11.8 \pm 20.2$ \\
\hline & $\chi^{2}(P)$ & $1.101(0.342)$ & $1.518(0.342)$ & $9.599\left(0.000^{\star}\right)$ & $0.365(0.542)$ & $4.421\left(0.000^{\star}\right)$ \\
\hline
\end{tabular}

Abbreviations: See Table 1, VF, Visuospatial function; FE, Frontal/Executive function.

${ }^{*} p<0.05$.

blood factors and GDS. In the correlation between blood factors and GDS, BUN and Creatinine showed negative correlation to TB $(P<0.05)$, and uric acid showed positive correlation $(P<0.01)$. The Uric acid also showed positive correlations with potassium $(P<0.05)$, and GDS and ALT showed negative correlation $(P<0.01)$.

\section{DISCUSSION}

The appropriate cut-off score and validity for the screening of dementia were presented based on the results of clinical studies. However, it is not calculated by surveying the residents of the community. Therefore, these tools should be used appropriately for the purpose of screening dementia. It is necessary to verify the validity of the questionnaire to the residents of the community.

The pathology of dementia, especially $\mathrm{AD}$, which is focused on in the following section, includes: (1) loss of neurons in the temporal lobes and hippocampus; (2) NFTs; (3) SPs that consist of amyloid- $\beta$ ( $A \beta)$; and (4) amyloidopathy of the cerebrovasculature [14].

Increased $\beta$-amyloid load mediated by the APOE $\varepsilon 4$ allele may lead to an increase in a-synuclein aggregation and toxicity via stabilization in the formation of hybrid nanopores [15] or through a direct connection between intracellular a-synuclein and extracellular APOE and $\beta$-amyloid [16].

A typical rating scale for patients with dementia is 
Table 5. Correlation between blood factors and GDS $(r(P))$

\begin{tabular}{|c|c|c|c|c|c|c|c|c|c|c|c|}
\hline & $\mathrm{TC}$ & TB & UA & AST & ALT & BUN & $\mathrm{Cr}$ & $\mathrm{Na}$ & K & $\mathrm{Cl}$ & GDS \\
\hline TC & 1 & & & & & & & & & & \\
\hline TB & $\begin{array}{c}0.153 \\
(0.095)\end{array}$ & 1 & & & & & & & & & \\
\hline UA & $\begin{array}{c}0.104 \\
(0.258)\end{array}$ & $\begin{array}{c}-.023 \\
(0.806)\end{array}$ & 1 & & & & & & & & \\
\hline AST & $\begin{array}{c}0.026 \\
(0.782)\end{array}$ & $\begin{array}{c}0.145 \\
(0.115)\end{array}$ & $\begin{array}{c}0.046 \\
(0.616)\end{array}$ & 1 & & & & & & & \\
\hline ALT & $\begin{array}{c}0.035 \\
(0.703)\end{array}$ & $\begin{array}{c}0.039 \\
(0.674)\end{array}$ & $\begin{array}{c}0.140 \\
(0.127)\end{array}$ & $\begin{array}{l}0.772^{\star *} \\
(0.000)\end{array}$ & 1 & & & & & & \\
\hline BUN & $\begin{array}{l}-0.031 \\
(0.739)\end{array}$ & $\begin{array}{c}-0.223^{*} \\
(0.014)\end{array}$ & $\begin{array}{l}0.412^{\star \star} \\
(0.000)\end{array}$ & $\begin{array}{l}-0.126 \\
(0.170)\end{array}$ & $\begin{array}{l}-0.124 \\
(0.176)\end{array}$ & 1 & & & & & \\
\hline $\mathrm{Cr}$ & $\begin{array}{l}-0.060 \\
(0.515)\end{array}$ & $\begin{array}{c}-0.231^{*} \\
(0.011)\end{array}$ & $\begin{array}{l}0.385^{\star *} \\
(0.000)\end{array}$ & $\begin{array}{l}-0.001 \\
(0.989)\end{array}$ & $\begin{array}{l}-0.035 \\
(0.701)\end{array}$ & $\begin{array}{l}0.494^{\star \star} \\
(0.000)\end{array}$ & 1 & & & & \\
\hline $\mathrm{Na}$ & $\begin{array}{c}0.167 \\
(0.069)\end{array}$ & $\begin{array}{c}0.104 \\
(0.258)\end{array}$ & $\begin{array}{c}0.129 \\
(0.160)\end{array}$ & $\begin{array}{c}-0.052 \\
(0.570)\end{array}$ & $\begin{array}{l}-0.041 \\
(0.660)\end{array}$ & $\begin{array}{c}0.018 \\
(0.846)\end{array}$ & $\begin{array}{l}-0.081 \\
(0.381)\end{array}$ & 1 & & & \\
\hline K & $\begin{array}{c}0.086 \\
(0.351)\end{array}$ & $\begin{array}{l}-0.056 \\
(0.541)\end{array}$ & $\begin{array}{l}0.233^{\star} \\
(0.011)\end{array}$ & $\begin{array}{c}0.152 \\
(0.098)\end{array}$ & $\begin{array}{c}0.132 \\
(0.152)\end{array}$ & $\begin{array}{l}0.388^{\star \star} \\
(0.000)\end{array}$ & $\begin{array}{c}0.111 \\
(0.226)\end{array}$ & $\begin{array}{c}0.105 \\
(0.255)\end{array}$ & 1 & & \\
\hline $\mathrm{Cl}$ & $\begin{array}{c}0.127 \\
(0.167)\end{array}$ & $\begin{array}{c}0.026 \\
(0.781)\end{array}$ & $\begin{array}{c}0.136 \\
(0.138)\end{array}$ & $\begin{array}{l}-0.039 \\
(0.670)\end{array}$ & $\begin{array}{l}-0.029 \\
(0.757)\end{array}$ & $\begin{array}{c}0.111 \\
(0.227)\end{array}$ & $\begin{array}{l}-0.007 \\
(0.944)\end{array}$ & $\begin{array}{l}0.675^{\star \star} \\
(0.000)\end{array}$ & $\begin{array}{l}0.190^{\star} \\
(0.038)\end{array}$ & 1 & \\
\hline GDS & $\begin{array}{l}-0.104 \\
(0.259)\end{array}$ & $\begin{array}{l}-0.088 \\
(0.338)\end{array}$ & $\begin{array}{l}-0.068 \\
(0.463)\end{array}$ & $\begin{array}{l}-0.165 \\
(0.071)\end{array}$ & $\begin{array}{c}-0.259^{* *} \\
(0.004)\end{array}$ & $\begin{array}{c}0.063 \\
(0.493)\end{array}$ & $\begin{array}{c}0.090 \\
(0.329)\end{array}$ & $\begin{array}{l}-0.239 \\
(0.009)\end{array}$ & $\begin{array}{l}-0.005 \\
(0.957)\end{array}$ & $\begin{array}{c}-0.089 \\
(0.332)\end{array}$ & 1 \\
\hline
\end{tabular}

Abbreviations: See Table 1.

${ }^{*} P<0.01,{ }^{*} P<0.05$.

Clinical Dementia Rating (CDR) scale [17] and Global Deteration Scale (GDS) [18]. GDS and CDR are the criteria for the severity of dementia in clinical studies Clinical trials are the most widely used criteria for evaluating the efficacy of dementia drugs. GDS is a detailed classification of early cognitive impairments, so GDS can be used as a test tool for clinical trials of dementia treatments or early diagnosis of dementia.

Brain-derived biomarkers are typically present at relatively low concentrations in the blood because of the blood-brain barrier preventing free passage of molecules, targeted blood-based biomarkers (plasma $\mathrm{A} \beta$, described in the AlzBiomarker database (https://www.alzforum.org/ alzbiomarker), plasma tau, plasma neurofilament light, hsa-miR-125b , plasma A $\beta 42 / A \beta 40$ ratio [19]. Both low and high serum magnesium levels are associated with an increased risk of all-cause dementia [20].

Recently, experiments have also shown that their expression levels are altered in both presbycusis and $\mathrm{AD}$ mouse models. Therefore, we propose that exploring the specific molecular link between presbycusis and $\mathrm{AD}$ may provide new ideas for their prevention and treatment [21].
A strength of this study is that the measures used with both groups were very similar, facilitating comparisons. Limitations of this study include a small sample size and data that are cross-sectional in nature. Additionally, although many investigators stress the role of diet in regulating potassium levels, information was not available for these participants.

Association between sUA (serum uric acid) and dementia/cognitive impairment was weak across undifferentiated dementia groups [22]. Higher homocystein levels, lower educational attainment, and decreased physical activity were particularly strong predictors of incident $\mathrm{AD}$ [23]. Higher levels of the minerals iron and copper were identified as being related to increased risk for $\mathrm{AD}$ but the role of other minerals (such as potassium) in cognitive decline was not addressed. Different lab abnormalities at the time of peak metabolic dearrangement accounted for unique patterns of neuropsychological impairment.

Recently, They found that a higher potassium level in $\mathrm{MCI}$ participants was predictive of MCI status. These findings contradict our premise of lower potassium levels 
that are related to MCI status. A plausible explanation may be the different socioeconomic status and biological components in our population [24].

Various risk or protective factors for dementia syndrome or cognitive impairment have been suggested by numerous epidemiological studies [25]. However, we still do not know much about the mechanisms through which various lifetime experiences such as physical and mental activity, social relationships, stress experiences, personality, diet and nutrition, and sleep, and many aging-related physiological or pathological changes in the human body, such as vascular status, hormonal changes, glucose or lipid metabolism, and body mass index (BMI).

In future, proteomical factors, biochemical and genetic analyses using blood and DNA specimen are also ongoing. Additionally, external validity of candidate biomarkers will be tested by using the data and samples collected from an independent cohort that is established for validation of candidate biomarkers discovered in cognitive impairments.

\section{요 약}

신경인지검사는 외래에서 전반적인 인지기능 정도를 평가하 는 MMSE (Mini-Mental State Examination)가 가장 보편적이 지만, 최근에는 SNSB II (Seoul Neuropsychological Screening Battery II)를 통해 심층적으로 진단에 활용된다. 2017년부터 2018년까지 경기도 남부지역 일개 의료원에 내원한 보건소에 서 정밀검사 의뢰된 노인층 120 명의 통상적인 신경인지검사 결 과와 혈액검사 항목을 후향적으로 조사하였다. GDS의 하위 영 역의 평가에서는 시공간 능력이 높게 나타났다. 그리고 혈액 전 해질 중 $\mathrm{Na}$ 이 GDS 수준이 증가함에 따라 통계적으로 유의한 감 소를 보였다. 또한 GDS 수준에 따른 집중력, 언어 시공간능력, 기억력, 전두엽 실행 기능이 통계적으로 유의한 감소를 보였다 $(P<0.001) . \mathrm{ALT}$ 와 크레아티닌이 정상군과 비정상군에서 전두 엽 실행 기능 영역이 통계적으로 유의한차이를 보였다 $(P<0.001)$. 또한 $\mathrm{GDS}$ 와 $\mathrm{ALT}$ 는 음의 상관성을 보였다 $(P<0.01)$. 결론적으 로 본 연구를 통해 선별 및 진단에 유의한 검사 항목을 개발하는 데 기초정보를 제공하고, 통상적인 혈액화학검사가 인지장애 환자의 진단 및 진행에 대한 기본 정보를 제공할 것으로 사료된다.
Acknowledgements: None

Conflict of interest: None

Author's information (Position): Kim SG ${ }^{1}$, M.T.; Park $\mathrm{CE}^{2}$, Professor.

\section{REFERENCES}

1. Kim JM, Prince MJ, Shin IS, Yoon JS. Validity of Korean form of Geriatric depression scale (KGDS) among cognitively impaired Korean elderly and development of a 15-item short version (KGDS-15). Int J Met Psychiatr Res. 2001;10:204-210. https://doi.org/10.1002/mpr.117.

2. Kim JM, Shin IS, Yoon JS, Lee HY. Comparison of diagnostic validities between MMSE-K and K-MMSE for screening of dementia. J Korean Neuropsychiatr Assoc. 2002;42:124-130.

3. Kang Y, Na DL, Hahn S. A validity study on the Korean mini-mental state examination (K-MMSE) in dementia patients. J Korean Neuropsychiatr Assoc. 1997;15:300-308.

4. Oh E, Kang Y, Shin JH, Yeon BK. A validity study of K-MMSE as a screening test for dementia: comparison against a comprehensive neuropsychological evaluation. Dement Neurocognitive Disord. 2010;9:8-12.

5. Hoops S, Nazem S, Siderowf AD, Duda JE, Xie SX, Stern MB, et al. Validity of the MoCA and MMSE in the detection of MCI and dementia in Parkinson disease. Neurology. 2009;73:1738-1745.

6. Svensson T, Sawada N, Mimura M, Nozaki S, Shikimoto R, Tsugane $\mathrm{S}$. The association between midlife serum high-density lipoprotein and mild cognitive impairment and dementia after 19 years of follow-up. Transl Psychiatry. 2019;9:26. https://doi.org/10.1038/s41398-018-0336-y.

7. Mills JH, Megerian CA, et al. Presbyacusis and presbyastasis. In: Snow JB, Wackym, editors. Ballenger's manual of otorhinolaryngology head and neck surgery. 17th ed. Shelton: People's medical publishing house; 2009. p333-343.

8. Livingston G, Sommerlad A, Orgeta V, Costafreda SG, Huntley J, Ames D, et al. Dementia prevention, intervention, and care. Lancet. 2017;390:2673-2734. https://doi.org/10.1016/S01406736 (17)31363-31366.

9. Ozawa M, Ninomiya T, Ohara T, Hirakawa Y, Doi Y, Hata J, et al, Self-reported dietary intake of potassium, calcium, and magnesium and risk of dementia in the Japanese: the Hisayama Study. J Am Geriatr Soc. 2012;60:1515-1520.

10. Sims Wright R, Levy SA, Katzel LI, Rosenberger WF, Manukyan Z, Whitfield KE. Fasting glucose and glucose tolerance as potential predictors of neurocognitive function among nondiabetic older adults. J Clin Exp Neuropsychol. 2015;37:49-60. https://doi.org/10.1080/13803395.2014.985189.

11. Anfinson TJ, Kathol RG. Screening laboratory evaluation in psychiatric patients: a review. Gen Hosp Psychiatry. 1992;14: 248-257.

12. Sheline Y, Kehr C. Cost and utility of routine admission laboratory testing for psychiatric inpatients. Gen Hosp Psychiatry. $1990 ; 12: 329-34$.

13. Reisberg B, Ferris SH, de Leon MJ, Crook T. The global deterio- 
ration scale (GDS) for assessment of primary degenerative dementia. Am J Psychiatry. 1982;139:1136-1139. https://doi.org/10.1176/ajp.139.9.1136.

14. Hyman BT. New neuropathological criteria for Alzheimer disease. Arch Neurol. 1998;55:1174-1176. https://doi.org/10.1001/ archneur.55.9.1174.

15. Tsigelny IF, Crews L, Desplats P, Shaked GM, Sharikov Y, Mizuno $\mathrm{H}$, et al. Mechanisms of hybrid oligomer formation in the pathogenesis of combined Alzheimer's and Parkinson's diseases. PLoS One 2008;3:e3135. https:// doi.org/10.1371/ journal.pone.0003135.

16. Gallardo G, Schluter OM, Sudhof TC. A molecular pathway of neurodegeneration linking alpha-synuclein to Apo $\mathrm{E}$ and $\mathrm{A}$ beta peptides. Nat Neurosci. 2008;11:301-308.

17. Choi SH, Na DL, Lee BH, Hahm D, Jeong JH, Yoon SJ, et al. Estimating the validity of the Korean version of expanded Clinical Dementia Rating (CDR) Scale. J Korean Neurol Assoc. 2001;19:585-591.

18. Heller S, Steinberg A, Sedler M. Validation of the english version of the multimodal assessment of capacities in severe dementia (MAC-SD): A cognitive and functional scale for use in severe dementia. J Alzheimers Dis Rep. 2017;1:249-262. https:// doi.org/10.3233/ADR-170038.

19. Zetterberg H, Burnham SC. Blood-based molecular biomarkers for Alzheimer's disease. Mol Brain. 2019;12:26. https:// doi.org/10.1186/s13041-019-0448-1.
20. Kieboom BCT, Licher S, Wolters FJ, Ikram MK, Hoorn EJ, Zietse $\mathrm{R}$, et al. Serum magnesium is associated with the risk of dementia. Neurology. 2017;89:1716-1722. https://doi.org/10.1212/ WNL.0000000000004517.

21. Shen Y, Ye B, Chen P, Wang Q, Fan C, Shu Y, et al. Cognitive decline, dementia, Alzheimer's disease and presbycusis: examination of the possible molecular mechanism. Front Neurosci. 2018;12:394. https://doi.org/10.3389/fnins.2018.00394.

22. Khan AA, Quinn TJ, Hewitt J, Fan Y, Dawson J. Serum uric acid level and association with cognitive impairment and dementia: systematic review and meta-analysis. Age (Dordr). 2016;38:16. https://doi.org/10.1007/s11357-016-9871-8.

23. Beydoun MA, Beydoun HA, Gamaldo AA, Teel A, Zonderman AB, Wang Y. Epidemiologic studies of modifiable factors associated with cognition and dementia: systematic review and meta-analysis. BMC Public Health. 2014;14:643. https://doi.org/10.1186/1471-2458-14-643.

24. Vintimilla RM, Large SE, Gamboa A, Rohlfing GD, O'Jile JR, Hall JR, et al. The link between potassium and mild cognitive impairment in Mexican-Americans. Dement Geriatr Cogn Dis Extra. 2018;8:151-157. https://doi.org/10.1159/000488483.

25. Wang HX, MacDonald SW, Dekhtyar S, Fratiglioni L. Association of lifelong exposure to cognitive reserve-enhancing factors with dementia risk: a community-based cohort study. PLoS Med. 2017;14:E1002251. 